\title{
The Plant Pathogen Rhodococcus fascians Colonizes the Exterior and Interior of the Aerial Parts of Plants
}

\author{
Karen Cornelis, ${ }^{1,2}$ Tita Ritsema, ${ }^{1}$ Jaap Nijsse, ${ }^{3}$ Marcelle Holsters, ${ }^{1}$ Koen Goethals, ${ }^{1}$ \\ and Mondher Jaziri² \\ ${ }^{1}$ Vakgroep Moleculaire Genetica \& Departement Plantengenetica, Vlaams Interuniversitair Instituut voor \\ Biotechnologie, Universiteit Gent, K.L. Ledeganckstraat 35, B-9000 Gent, Belgium; ' ${ }^{2}$ aboratoire de \\ Biotechnologie Végétale, Université Libre de Bruxelles, Chaussée de Wavre 1850, B-1160 Brussels, \\ Belgium; ${ }^{3}$ Laboratory of Experimental Plant Morphology and Cell Biology, Department of Plant Science, \\ Wageningen University, Marijkeweg 22, NL-6709 PG Wageningen, The Netherlands \\ Accepted 9 January 2001.
}

\begin{abstract}
Rhodococcus fascians is a plant-pathogenic bacterium that causes malformations on aerial plant parts, whereby leafy galls occur at axillary meristems. The colonization behavior on Nicotiana tabacum and Arabidopsis thaliana plants was examined. Independent of the infection methods, $R$. fascians extensively colonized the plant surface where the bacteria were surrounded by a slime layer. $R$. fascians caused the collapse of epidermal cells and penetrated intercellularly into the plant tissues. The onset of symptom development preceded the extensive colonization of the interior. The meristematic regions induced by pathogenic strain D188 were surrounded by bacteria. The nonpathogenic strain, D188-5, colonized the exterior of the plant equally well, but the linear plasmid (pFiD188) seemed to be involved in the penetration efficiency and colonization of tobacco tissues.
\end{abstract}

Additional keywords: cytokinin, shoot induction.

The gram-positive bacterium Rhodococcus fascians is a plant pathogen that interferes with the development and growth of a wide variety of hosts, causing malformations and retarded growth. The nature and position of the malformations depend upon the host species and the infection method (Crespi et al. 1992; Lacey 1936a; Vereecke et al. 2000). The most severe symptom is a leafy gall that consists of multiple shoots and shoot primordia (Vereecke et al. 2000). The shoots originate from existing meristematic tissues and de novo-initiated meristems (Manes et al. 2001). Outbreaks of $R$. fascians in ornamental plants species such as Dahlia and Lilium spp. can cause serious financial losses (J. Van Doorn, personal communication).

The pathogenicity of $R$. fascians strain D188 depends upon a linear plasmid, pFiD188, that carries several virulence loci (Crespi et al. 1992; Crespi et al. 1994; Desomer

Corresponding author: M. Holsters, Vakgroep Moleculaire Genetica, Universiteit Gent, K.L. Ledeganckstraat 35, B-9000 Gent, Belgium; Fax: +32 9 2645349; E-mail: mahol@gengenp.rug.ac.be

Current address of T. Ritsema: Molecular Plant Physiology, University Utrecht, Padualaan 8, NL-3584 CH Utrecht, The Netherlands. et al. 1988). A derivative of strain D188, strain D188-5, which is cured for the linear plasmid, becomes nonpathogenic.

The molecular analysis of the $R$. fascians pathology has been performed with Arabidopsis thaliana and Nicotiana tabacum as model plants. Several infection methods have been used: seedling infection, by applying a drop of bacterial suspensions; vacuum infiltration of plants with bacteria; and decapitation followed by infection of the wound site (Vereecke et al. 2000). Seedling infection of tobacco results in small, stunted plantlets (Crespi et al. 1992), whereas infected $A$. thaliana seedlings develop bunches of shoots. Infiltration of tobacco gives rise to small leafy galls at axillary meristems, petioles, and veins of the leaves (Vereecke et al. 2000), whereas infiltrated A. thaliana form numerous shoots and malformed leaves (T. Ritsema, unpublished data). After wound infection of tobacco, large leafy galls are formed (Crespi et al. 1992).

$R$. fascians has been isolated from infected plants (FaivreAmiot 1967; Lacey 1936a; Lacey 1936b; Tilford 1936) and was found on the surface and in epidermal cells of sweet pea seedlings (Lacey 1936b). Studies of plant-pathogenic bacteria that colonize the interior of leaves are limited (Beattie and Lindow 1999).

The goal of the present study was to localize the bacteria on the aerial parts of plants during the infection process. To better understand the influence of the infection method on symptom development, the origin and structure of leafy galls provoked with different infection methods were examined. To investigate the interaction of $R$. fascians with single plant cells, Bright Yellow-2 (BY-2) tobacco cultures were infected and the influence of the virulence plasmid on colonization was analyzed by comparing wild-type D188 and the nonpathogenic strain D188-5.

We opted for scanning electron microscopy (SEM) for a detailed examination of surface colonization. In situ hybridization (ISH) was used to study the location of $R$. fascians inside plants (Amann et al. 1995; DeLong et al. 1989). Here, we present a protocol for the in situ detection of $R$. fascians on plant sections and seedlings and provide an overview of the colonization of the aerial plant parts by $R$. fascians. 


\section{RESULTS}

\section{Leafy galls provoked with different infection methods have a common origin and structure.}

Previously, spot inoculation of bacteria has been shown to lead to a proliferation of de novo-formed and existing axillary meristems, which are the origins of leafy galls (Manes et al. 2001; Vereecke et al. 2001). The origin of the leafy galls that develop after decapitation, however, was unknown. Upon infection with strain D188-5 or in mock inoculations, the top axil was activated to form a shoot (data not shown). Infection with strain D188 after decapitation also led to the activation of the top axil (Fig. 1I), but its outgrowth was inhibited and, at its base, numerous meristems emerged from which new shoot primordia developed (Fig. 1J). By the continuing generation of new primordia, the original infection site gradually broadened and was incorporated into the developing structure, resulting in a very compact leafy gall.

An infection method that omits any mechanical force was used to evaluate the intrinsic colonizing capacities of $R$. fascians. Arabidopsis and tobacco plants were dipped in a bacterial suspension. The resulting symptoms were similar to those after vacuum infiltration (data not shown). Hence, infections by dipping, vacuum infiltration, or after decapitation all activated axillary meristems, resulting in leafy gall formation.

Staining sections of developing leafy galls with alcian green safranin revealed regions of small cells in malformed parts. Such meristematic areas were observed on petioles, stems, and in axillary buds of infiltrated tobacco plants as well as in the developing leafy gall formed after decapitation (Fig. $1 \mathrm{H}$ and I; data not shown).

\section{Rhodococcus fascians colonizes the phylloplane.}

SEM was used to investigate how $R$. fascians colonizes the plant surface. On A. thaliana and N. tabacum, no difference in surface colonization was seen. With all infection methods, the surface colonization by the pathogenic D188 wild-type strain (number of examined plants: $n=57$ for A. thaliana, $n=34$ for tobacco) was comparable to that of the nonpathogenic strain D188-5 ( $n=26$ for $A$. thaliana, $n=8$ for tobacco). Independent of the infection method, the number of bacteria observed on the plant surface increased with time. At the earliest time point examined (3 days postinfection), few bacteria were observed.

After vacuum infiltration, dipping, or seedling infection, $R$. fascians was mostly found on the lamina of the leaves, where colonies of variable sizes were formed. The largest of these colonies covered up to half a leaf. Most of the large colonies were found on the older leaves, whereas younger leaves generally held smaller and dispersed colonies. When a leaf was less densely colonized, most of the bacteria were at the epidermal cell wall junctions (Fig. 1B). The upper and lower sides of the leaf were colonized, without preference for either side. Bacterial colonization was most pronounced at the periphery of the leaves and decreased from tip to base (Fig. 1C). Almost no bacteria were observed on the petioles. Few bacteria were observed in proximity to the veins. There was no distinct colocalization of bacteria with the stomata, except after infection by vacuum infiltration (Fig. 1D). Bacteria were not present in higher numbers in the vicinity of the trichomes. Some colonization was seen on tobacco stems and the crown of Arabidopsis. Colonies on these plant parts were small and covered only a few plant cells (data not shown).

After infection of decapitated tobacco, bacteria grew on the wound site and did not spread over the surface to the lower plant parts (data not shown) ( $n=19$ for D188, $n=5$ for D1885). Occasionally, D188-5 was seen on the newly formed shoot apex.

Initially, the bacteria on the plant surface were rod shaped and 1 to $3 \mu \mathrm{m}$ in length. After several weeks, very long hyphae $(\geq 10 \mu \mathrm{m})$ were seen (Fig. 1E). Occasionally, a rod structure was formed at one of the extremities of a hyphae (data not shown). U- or V-shaped bacterial forms were noticed. The presence of a cell wall at the junction indicated that these were dividing bacteria (data not shown). Previous studies in which the bacteria were grown on synthetic medium reported the existence of such forms, and $R$. fascians has been described as being pleomorphic (Miller et al. 1980).

SEM was used to observe a layer that covered the bacteria. In some places, this layer looked undisturbed, whereas at other sites bacteria were puncturing through it (Fig. 1F). Because the original appearance of this slime layer could have been changed by the fixation and dehydration procedures preceding the SEM, cryo-SEM was performed on A. thaliana seedlings $(n=5)$. A less disturbed image of the slime layer was thus obtained (Fig. 1D and H). Some plant cells in the vicinity of bacterial colonies were collapsing (Fig. $1 \mathrm{G}$ and $\mathrm{H}$ ).

\section{Colonization of the inner tissue of plants.}

For the examination of the internal colonization of the plant, ISH was performed with an oligonucleotide probe linked to the fluorophore rhodamine, targeted to a conserved region of the 16S rRNA of bacteria (Amann et al. 1995; DeLong et al. 1989). A protocol for the detection of $R$. fascians was developed (see below). For bacterial cultures, a signal was obtained with all protocols described below. In a plant environment, the procedure comprising a two-phase fixation and a permeabilization step involving proteinase $\mathrm{K}$ and sodium lauryl sulfate (SDS) generated the best signals. Uninfected plants gave no signal.

At the onset of inoculation by all infection methods, bacteria were detected at the outside of plants. Approximately 1 week after infection with strain D188 symptoms started to appear and only a few bacteria were present inside the plant. The number of bacteria inside the plant increased progressively with time.

Independent of the infection method used on tobacco, groups of D188 bacteria penetrated the plant tissue (on approximately $70 \%$ of the plants). The plant cells surrounding these bacteria exhibited an increased autofluorescence (Fig. 2A). These groups of penetrating bacteria, termed ingressions, became larger and, after 2 weeks, extended through four cell layers of the plant tissues (Fig. 2A). These ingressions were found on leaves, stems, and axils.

After wound infection of tobacco plants, bacteria penetrated into the stem at the wounding site. After 1 week, the penetrating bacteria descended down the stem, approximately to the region of the first activated axil but not to the axil itself (data not shown).

After infection by infiltration or plant dipping (50 and 24 plants examined for tobacco and Arabidopsis, respectively) with strain D188, bacteria often were observed in the sub- 
stomatal area but did not spread from the stomata throughout the underlying tissues. The bacteria extensively colonized the epidermal layer and, to a smaller extent, the parenchymatous tissues. On tobacco, this decrease in the amount of bacteria toward the inner tissues of the plant was much more pronounced than on A. thaliana. Leaves without visible symptoms were colonized in a similar manner (Fig. 2B). The majority of the bacteria were intercellular, although some
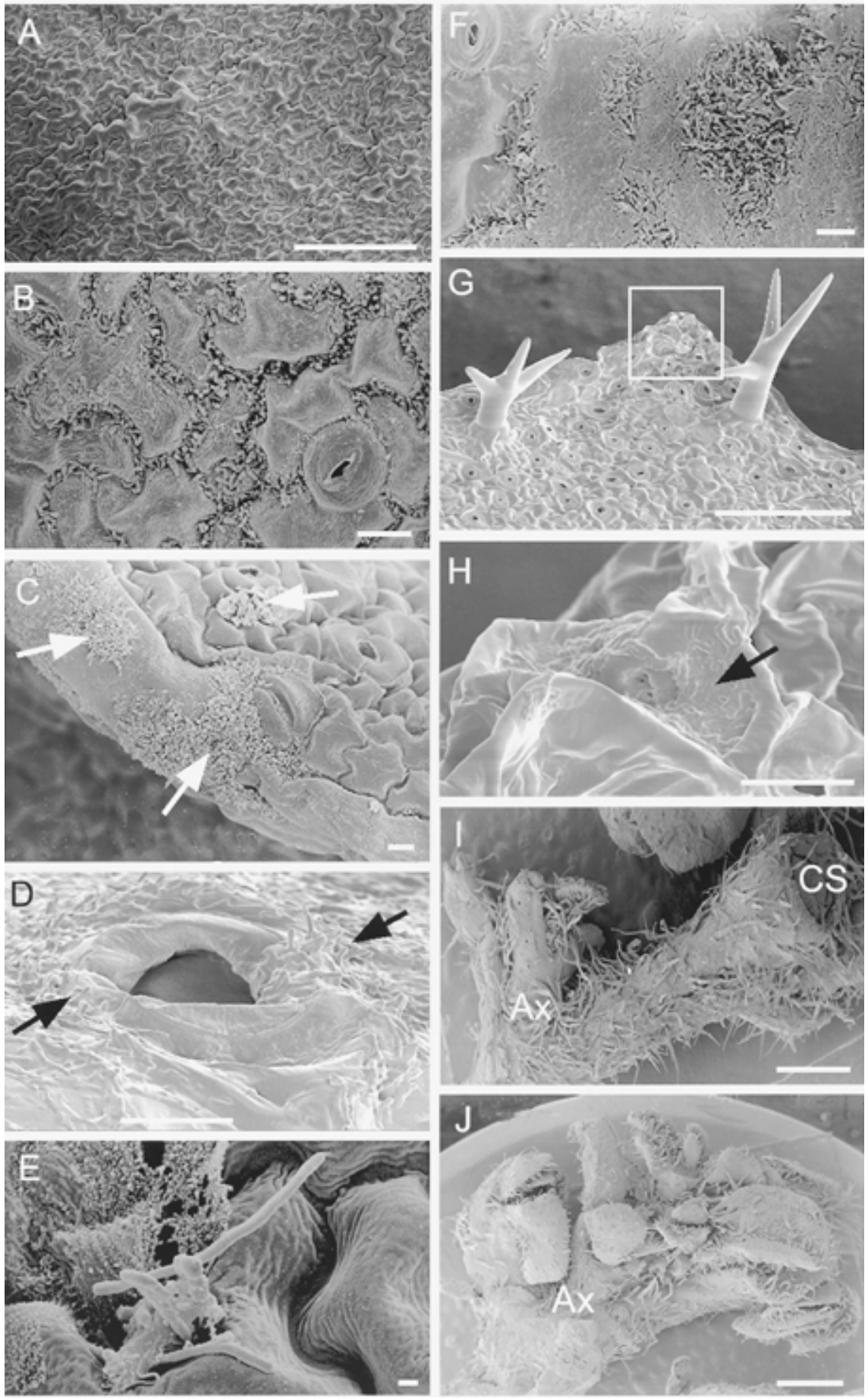

Fig. 1. Surface colonization by Rhodococcus fascians on Arabidopsis thaliana. A, Surface of an uninfected control leaf. B, R. fascians at epidermal cell wall junctions (10 days postinoculation). C, $R$. fascians (arrows) on the periphery of the leaves (3 weeks postinoculation). D, $R$. fascians in stomata after vacuum infiltration. Bacteria (arrows) are surrounded by a slime layer (4 weeks postinoculation). E, Hyphae-like bacteria after 4 weeks infection. F, Skin-like layer covering a bacterial colony (10 days postinoculation). G, Collapsed plant cells and intact trichomes, confirming that collapse is not resulting from the preparation (4 weeks postinoculation). $\mathbf{H}$, Enlargement of indicated area in $\mathbf{G}$, bacteria embedded in slime layer are colonizing the collapsed plant cells (arrow). I and J, Decapitated tobacco plant with activated axillary meristem (3 days) and developing leafy gall (7 days), respectively. Scanning electron microscopy (SEM) (A-C, E, F, I, and J) and cryo-SEM images (D, G, and $\mathbf{H})$. Arrows point to bacterial groups. Ax, axil: cs, cutting site. $\operatorname{Bars}=1 \mu \mathrm{m}(\mathbf{E}), 10 \mu \mathrm{m}(\mathbf{A}-\mathbf{D}, \mathbf{F}$, and $\mathbf{H}), 100 \mu \mathrm{m}(\mathbf{G})$, and $1 \mathrm{~mm}(\mathbf{I}$ and $\mathbf{J})$. 
bacteria surrounded by a plant cell wall could represent intracellular forms. This was observed in epidermal and in parenchymatous cells (data not shown).

In leafy galls on tobacco (110 plants examined), bacteria were found throughout the proliferating tissues (Fig. 2E), and their number increased with time. On sections of developing leafy galls, multiple meristematic regions (Fig. 3E and F) were observed under the fluorescence microscope as areas with many plant cell nuclei in close proximity to each other (Fig. 2F and G). ISH showed bacteria surrounding these meristematic areas, but very few bacteria inside these regions (Fig. 2H and I).

Whole-mount ISH on seedlings of tobacco infected with D188 provided similar findings. Again, the bacteria were detected mainly in the epidermis and at the edges of the leaves, and ingressions could be observed. Repeatedly, the bacteria were surrounded by the wall of a single plant cell (Fig. 3A). Putative intracellular bacteria were found on 25,50 , and $100 \%$ of the examined plants after 9, 16, and 21 days of infection, respectively. Examination of plants infected with different methods did not reveal a single occurrence of $R$. fascians in vascular tissues.

Samples from plants infected with the nonpathogenic strain D188-5 were examined by ISH. The colonization was less extensive than with D188. On tobacco plants infected after decapitation, the uppermost axillary bud developed into a normal shoot. The infection site harbored a small number of bacteria. The bacteria penetrated into the wound site, but did not reach the region of the first axil (data not shown). The interior of the leaf that appeared from the bud closest to the decapitation site was colonized weakly. On leaves that developed further away from the infection site, no bacteria were observed (number of plants examined: $n=40$ ).

After infection by infiltration or dipping with strain D188-5 (30 and 20 plants examined for tobacco and A. thaliana, respectively), the nonpathogenic strain colonized the inner tissues of the plants to a lesser extent than D188. This was more pronounced on tobacco plants than on A. thaliana (Fig. 2C and D), and ingressions remained smaller. After whole-mount ISH on tobacco seedlings, we could not observe putative intracellular D188-5 bacteria (30 examined plants; data not shown).

To provide quantitative data on the colonization of the exterior and interior of tobacco plants, colony-forming units (CFUs) from infected plants were determined, with or without a bleach treatment before plating. Sodium hypochloride (bleach) kills off bacteria on the surface and in open stomata and unprotected areas of the plant. Strains D188 and D188-5 were equally sensitive to bleach treatment. Three and five weeks postinfection, no difference in the number of CFUs per gram plant tissue was observed between the two strains without bleach treatment, whereas a significant difference was found between plants infected with strains D188 or D188-5 after bleach treatment $\left(F_{(1,47)}=25.2, p<0.001\right.$ for 3 weeks; $F_{(1,49)}=32.1, p<0.001$ for 5 weeks) (Fig. 4). This finding confirmed the results obtained with ISH, i.e., that pathogenic strain D188 colonized the interior of tobacco plants to a larger extent than the nonpathogenic strain. The number of CFUs found on a plant after bleach treatment rose over time with strain D188 and D188-5, indicating that the intraplant population of both strains increased (data not shown).
BY-2 tobacco cell cultures were inoculated to evaluate the infection of single plant cells by $R$. fascians. After infection of BY-2 cell cultures with D188, bacteria surrounded by the cell wall of BY2 cells could be detected (Fig. 3B). The proportion of infected plant cells varied with each experiment from a few invaded plant cells to approximately 20\% (1,000 cells examined in each experiment). Seldom did a plant cell contain a single bacterium; more often, a microcolony of variable size was present. The earliest time point at which bacteria were observed within the cell wall boundaries was 3 days after infection. The proportion of infected cells increased with time. When BY-2 cell cultures were infected with strain D188-5, far fewer tobacco cells were found to contain bacteria. In one experiment, in approximately $0.2 \%$ of 1,000 BY-2 cells examined, D188-5 bacteria were surrounded by the plant cell wall, whereas in two other experiments, no bacteria were found inside BY-2 cells (data not shown).

\section{$\boldsymbol{R}$. fascians proliferates in the stomata of decaying leaves.}

On decaying leaves of infected tobacco plants, large groups of bacteria became apparent as orange spots (Fig. 3C). They were colocalized mainly with the stomata. The bacteria did not spread over the growth medium. These spots were never observed on the healthy looking leaves.

When leaves of tobacco plants infected by dipping were separated 3 weeks after inoculation from the plant and placed on plant culture medium, similar spots of bacteria originated at the places where the leaves touched the medium. There was a higher occurrence of these spots on the older leaves than on the younger leaves. Paraffin sections stained with 4',6diamidino-2-phenylindole (DAPI) through these areas revealed that these spots colocalized with the slightly enlarged substomatal area, around which the plant cells had collapsed (Fig. 3D).

\section{DISCUSSION}

\section{Evaluation of detection strategies.}

We optimized a protocol for the visualization of $R$. fascians in a plant environment by ISH with a fluorescent-labeled oligonucleotide probe that was targeted at the 16S rRNA. Bacteria from batch cultures could be detected without a permeabilizing treatment, in contrast to an earlier report in which an acid pretreatment was necessary to obtain an ISH signal with $R$. fascians (Macnaughton et al. 1994). This difference might be a result of the two-phase fixation procedure that we used. For visualization of $R$. fascians with ISH in the rhizosphere of tomato and clover, however, no pretreatment was required (Macnaughton et al. 1996). In our hands, a permeabilization procedure involving proteinase $\mathrm{K}$ and SDS generated the strongest signal for visualizing bacteria in the phyllosphere.

\section{Appearance of $\boldsymbol{R}$. fascians on the leaf surface.}

On the plant surface, Chinese character, V, or Y forms were observed such as previously described in $R$. fascians cultures (Goodfellow 1984). These forms correspond to dividing bacteria that have not yet separated. After longer colonization times, bacteria become more elongated and undergo asymmetric division. The reason for this morphological change is unknown. $R$. fascians belongs to the Actinomycetes, several members of which produce hyphae (Miguélez et al. 1992; 
Wildermuth 1970), but such a feature has not been reported for $R$. fascians. For this nonmotile bacterium, asymmetric division could be a means of advancing over the plant surface. A change in shape also could represent an adaptation to longterm survival on the plant surface.

With cryo-SEM, a slime layer was observed that covers and embeds the bacteria. This layer was damaged during the conventional SEM procedure. Water-containing structures or layers have been reported to disintegrate during the dehydration procedure for SEM (Beattie and Lindow 1999; Chin-A-Woeng et al. 1997). This slime layer has never been observed on uninfected plants. Because transmission electron microscopy revealed capsules around $R$. fascians from cultures (D. Vereecke and K. Cornelis, unpublished results), we assume that the slime layer is of bacterial origin. The water-absorbing capacity of this layer might protect the bacteria from desiccation. A slime layer consisting of exopolysaccharides also may enhance attachment to the surface and make the environment around the bacterial cells more favorable for growth and survival (Beattie and Lindow 1995). Similar functions could be assigned to slime layers produced by various gram-positive Staphyllococcus sp. (Koenig et al. 1998; Raad et al. 1995; Souli et al. 1998). In addition, exopolysaccharides can play a role in the pathogenicity and/or the epiphytic fitness of some plant-pathogenic bacteria such as Pseudomonas syringae pv. syringae and Ralstonia solanacearum (Saile et al. 1997; Yu et al. 1999). Taking into account the roles of slime layers in other bacteria, we propose that in the $R$. fascians-plant interaction, this layer helps the bacteria to favorably modify the environment around them. The virulence plasmid of $R$. fascians is not involved in the production of this slime layer.

\section{Colonization.}

$R$. fascians was found to colonize the surface of $A$. thaliana and $N$. tabacum. The virulence plasmid pFiD188 does not influence the colonization capacity on the plant's surface. For some pathogenic bacteria, the hydathodes are an entry site to the leaves, as has been reported for Xanthomonas campestris pv. campestris (Hugouvieux et al. 1998). No evidence has been obtained that this is the case for $R$. fascians, but the presence of hydathodes at the sides and tips of leaves and the concomitant availability of nutrients could be a reason why the bacteria prefer the periphery of the leaves. $R$. fascians is often found in cavities and at epidermal cell wall junctions, which might represent a way to avoid environmental stress on the leaf (Beattie and Lindow 1995). Stomata could not be pinpointed as entry sites for $R$. fascians. Although the bacteria may reside in substomatal areas, they do not spread to other sites in the plant tissue. We presume that when leaves begin to decay, the bacteria already present in the stomatal areas proliferate saprophytically.

Leaves of infiltrated and dipped plants have collapsed plant cells at the surface sites where both D188 and D188-5 bacteria reside. On sections of tobacco, we observed ingressions of hundreds of bacteria at the location where the epidermal cell layers are damaged. Because strain D188-5 makes smaller ingressions, the full development of these ingressions might be correlated with the virulence plasmid pFiD188. Lacey (1936b) reported on the entry of $R$. fascians in the epidermis of sweet pea seedlings, which was associated with death of invaded cells and necrosis. We did not observe any necrosis, although the plant cells at some of these ingression sites exhibited an increased autofluorescence, possibly indicating that some plant defense reactions such as local synthesis of phenolic compounds occur at these sites. $R$. fascians infection has been shown previously to lead to the de novo synthesis of phenolics in tobacco plants (Vereecke et al. 1997).

Early symptom development precedes the colonization of the interior of the plants, suggesting that the bacteria on the exterior cause the initial symptom development by producing virulence factors (Crespi et al. 1992). Likewise, at the onset of symptom development after decapitation, the infecting bacteria are at a distance from the developing axillary meristem. Hence, the colonization of the interior of the plants does not seem necessary for the onset of symptom development, but it may play a role in sustaining the leafy galls. The presence of $R$. fascians does not always cause symptoms, suggesting that environmental factors affect the bacterial synthesis of virulence factors and/or that these virulence factors are effective only at certain sites of the plants.

Far fewer bacteria were found in the interior than on the surface of plants. On A. thaliana, no difference was observed between strains D188 and D188-5. In contrast, on tobacco, strain D188 penetrates more deeply into the tissue than does strain D188-5, which could partially be a result of the thinner leaves of $A$. thaliana. On tobacco leaves with dimensions similar to those of A. thaliana, however, D188-5 also was confined to the epidermis and the first parenchymal layer, suggesting that other host-related factors influence the colonization. In either case, the virulence plasmid is not required for the initial penetration. This finding that $R$. fascians colonizes the epidermis of $A$. thaliana and $N$. tabacum is in accordance with a previous report on the colonization of the epidermis of sweet pea seedlings by $R$. fascians (Lacey 1936b).

Many wilt-causing plant pathogens colonize the vascular tissues of the plants (Vasse et al. 1995). Additionally, the hyperplasia-inducing pathogen Agrobacterium tumefaciens colonizes the vascular tissues of transformed roots and shoots (De Buck et al. 2000; Matzk et al. 1996), but $R$. fascians could not be detected in these tissues.

$R$. fascians surrounds meristematic centers in infected tobacco plants. The bacteria might be attracted by meristematic regions as it is in Rhizobium sp., which triggers meristem formation while causing nodules on roots of leguminous plants. These bacteria induce the formation of a new nodule meristem in the cortex via the Nod factors and simultaneously invade the plants via an "infection thread" that grows until it reaches the nodule primordium (Hadri and Bisseling 1998; Nap and Bisseling 1990). Our observations with $R$. fascians showed no corridor of bacterial progression toward the formed meristematic centers. Because $R$. fascians can produce a cytokinin-like signal molecule (Crespi et al. 1992) that is possibly involved in the initiation and activation of meristematic activity (Manes et al. 2001; Vereecke et al. 2000), it is tempting to suggest that bacteria induce these meristematic areas and, thereafter, proliferate intercellularly around them.

In infected tissue and in BY-2 tobacco cultures, some bacteria are surrounded by the wall of a plant cell. In living plant cells where the cell membrane is adjacent to the wall, this could mean that the bacteria are located intracellularly. In dying cells, there is a breakdown of the nucleus and loosening of the membrane from the cell wall (Pennell and Lamb 1997). 
We did not observe any indications of decay or cell death in cells with bacteria. Lacey (1961) reported that leafy galls of sweat pea contain "L forms" of $R$. fascians, i.e., obligatory intracellular bacterial forms without a cell wall. This result was formed on the basis of growth characteristics of bacteria isolated from galls, not on microscopic observations. The ability of $R$. fascians to colonize BY2 cells is not linked with the presence of the virulence plasmid, although the plasmid
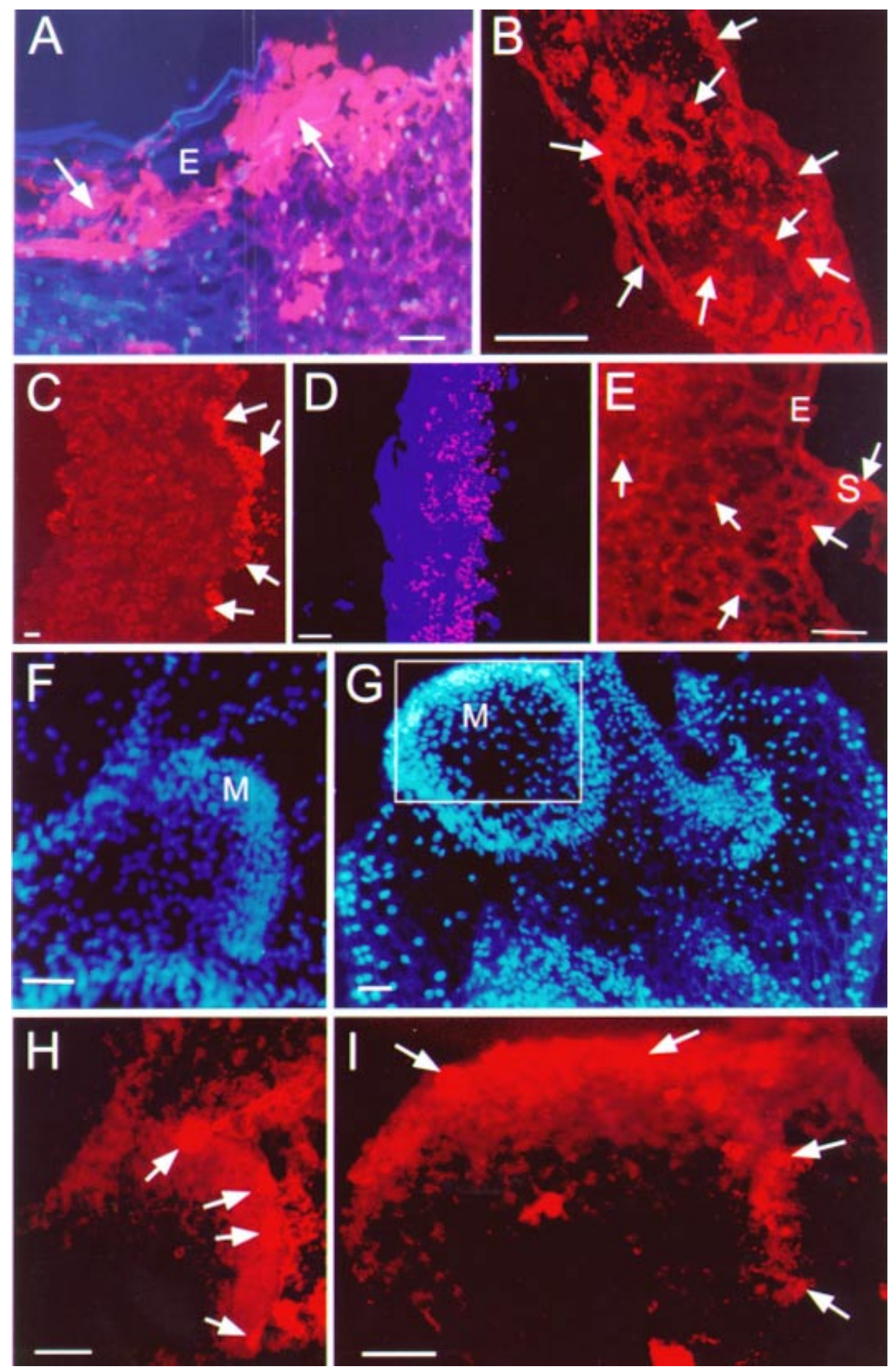

Fig. 2. Colonization of the interior of plants by Rhodococcus fascians visualized after in situ hybridization (ISH) on transversal 30- $\mu \mathrm{m}$ sections. Red corresponds to the probe signal (A-E, H, and I) and blue to the staining of the cell walls with fluorescent brightener 28 (A and D) or DNA stained with $4^{\prime}, 6$ diamidino-2-phenylindole (F and G). Arrows point to bacterial groups. A and, B, ISH on symptomless tobacco leaves, 14 days after infection by dipping with D188. A, Cell walls are stained. C and D, ISH on transversal sections through leaves of C, tobacco and D, Arabidopsis thaliana plants infected with D188-5, respectively, 14 days postinfection. The uniform red in $\mathbf{C}$ is the background of the plant material. $\mathbf{E}$, ISH transversal section through a leafy gall of tobacco, 3 weeks postinfection. F and $\mathbf{H}$, Transversal section through a meristematic area in a developing leafy gall of tobacco, 2 weeks postinfection. F, DNA staining. H, ISH signal. G and I, Transversal section through meristematic areas in a developing leafy gall of tobacco, 3 weeks postinfection. G, DNA staining. I, ISH signal in the indicated area of H. E, epidermis; M, meristematic zone; S, stomatum. Bars $=10 \mu \mathrm{m}(\mathbf{C}$ and D) and $100 \mu \mathrm{m}(\mathbf{A}, \mathbf{B}$, and E-I). 

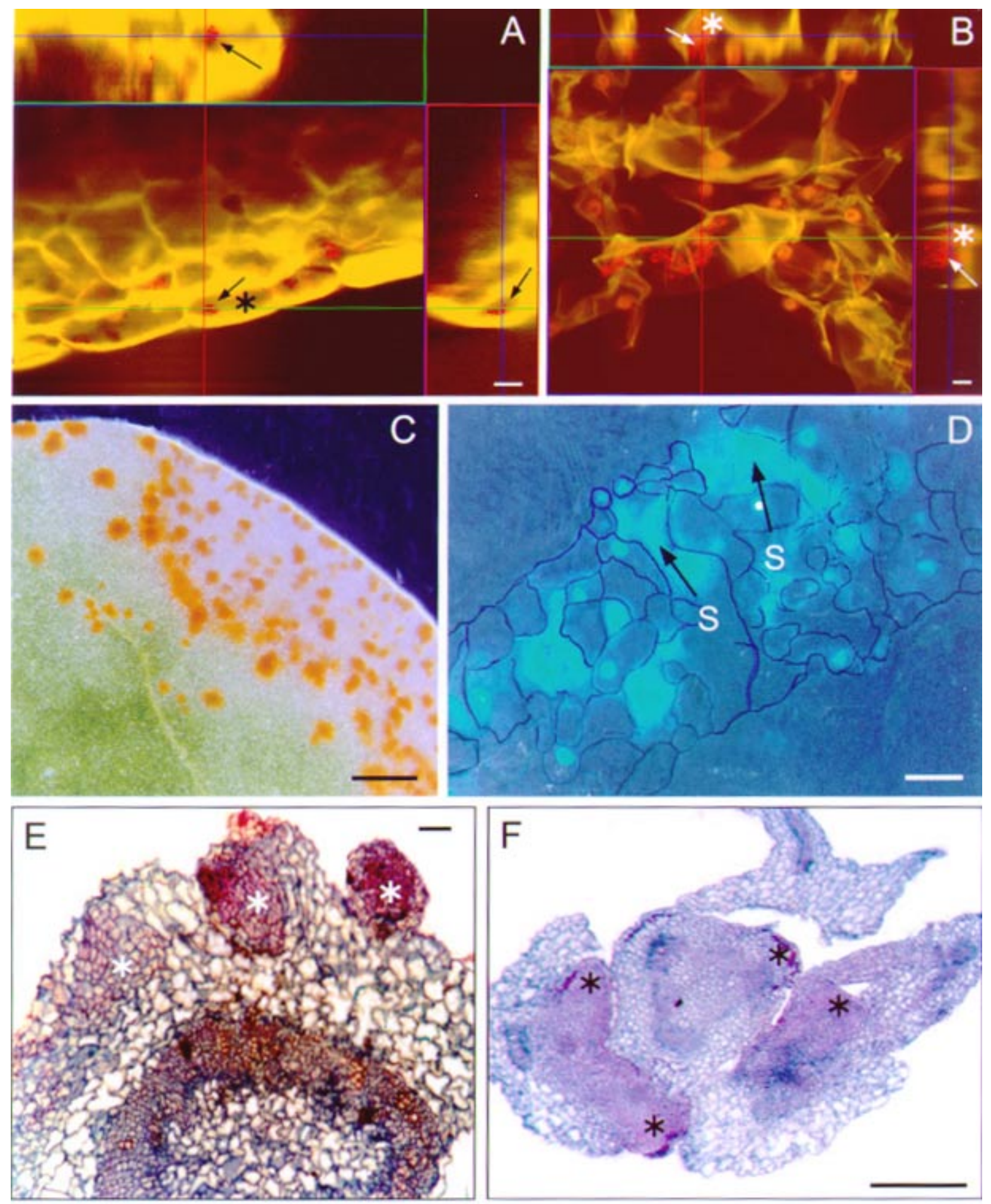

Fig. 3. Bacteria in plant environment. A and B, Confocal image of a stack of images through a D188-infected tobacco seedling after whole-mount in situ hybridization (ISH) and BY-2 cell culture after ISH, respectively, accompanied by z sections shown in the side panels taken at the sites indicated in the central image, indicated by colored lines. Yellow is the stain of cell walls and of DNA. Red is the ISH signal. Asterisks indicate nuclei and arrows point to bacteria. C, Decaying tobacco leaf harboring large groups of Rhodococcus fascians in the stomata. D, Section through a similar leaf as in $\mathbf{C}$, stained with 4',6-diamidino-2-phenylindole for DNA. Image results from an overlay of a bright-field picture with a UV-fluorescence picture. E, Section through a petiole of a tobacco plant dipped in D188, 7 days after infection, with meristematic areas developing. F, Section through an axillary bud of a tobacco plant dipped in D188, 7 days after infection, with proliferating meristems. $\mathbf{E}$ and $\mathbf{F}$, Asterisks denote proliferating meristematic areas. S, substomatal area. Bars $=10 \mu \mathrm{m}(\mathbf{A}$ and $\mathbf{B}), 1 \mathrm{~mm}(\mathbf{C}), 100 \mu \mathrm{m}(\mathbf{D}), 1 \mathrm{~mm}(\mathbf{E})$, and $0.1 \mathrm{~mm}(\mathbf{F})$. 
strongly increases the frequency. In plants, putative intracellular bacteria are found only after infection with the pathogenic strain. The role of this population in the pathogenicity is unclear: they are not necessary for the onset of symptom development because they appear later in the infection process, although they could be involved in maintaining the bacterial population in plants. Investigation of the expression of the virulence genes of $R$. fascians during infection could contribute to our understanding of the importance of the different bacterial populations to symptom development and maintenance.

\section{Model.}

$R$. fascians grows epiphytically on aerial plant surfaces, where it can proliferate while being embedded in a slime layer. The bacteria cause the collapse of some underlying plant cells, subsequently penetrating into the plant tissues via ingression sites. The bacteria on the surface of the plants produce the virulence factors that cause the early symptoms, i.e., the proliferation of meristematic regions. The de novo initiation and/or activation of meristems leads to the formation of a leafy gall occupied by $R$. fascians. In the plant, the bacteria are mainly intercellular. The respective roles of bacterial populations at different locations in sustaining the leafy gall are unclear. Plant parts can be colonized extensively without developing symptoms because some environmental elements that trigger the production of bacterial virulence factors are lacking or because these virulence factors have no effect at these sites. Upon decay of the plant, the bacteria present in the substomatal area start to proliferate, leading to a massive growth of the bacteria.

\section{MATERIAL AND METHODS}

Bacterial strains.

Rhodococcus fascians strains were grown for 2 days in YEB medium at $28^{\circ} \mathrm{C}$ (Miller 1972). The strains were D188 (pathogenic, with linear plasmid that confers virulence) and D188-5 (nonpathogenic, without linear plasmid) (Crespi et al. 1992; Desomer et al. 1988).

Plant material and infections.

Plants were grown according to Vereecke et al. (2000). $N$. tabacum (L.) Wisconsin 38 and A. thaliana (L.) Heynh. cv. Columbia plants were infected at approximately 4 and 1 to 2 weeks old, respectively. For infections, late-exponential 2day-old bacterial cultures were used with $10^{8}$ to $10^{9}$ bacteria per $\mathrm{ml}$. For seedling infections, a drop $(200 \mu \mathrm{l})$ of bacteria was applied as soon as the radicle emerged. For infection by dipping or vacuum infiltration, plants were submerged in a suspension of bacterial culture. The vacuum infiltration was performed for $5 \mathrm{~min}$. Infections by decapitation were performed as described by Vereecke et al. (2000).

BY-2 tobacco cells were cultured as described by Nagata et al. (1992). The cultures were infected 2 days after transfer to a fresh culture medium. One milliliter of $R$. fascians culture $\left(10^{8} \mathrm{CFU} / \mathrm{ml}\right)$ was added to $100 \mathrm{ml}$ of the culture medium. Samples were taken starting from day 1 after infection until day 9. The tobacco cells were then pelleted and resuspended in the two-phase fixation mixture described below.

\section{Fixation and pretreatments for in situ hybridization.}

Fixation was performed with $50 \%$ ethanol, $5 \%$ acetic acid, and $4 \%$ formaldehyde, followed by gradual dehydration of the samples or with a two-phase system, modified from Bauwens et al. (1997), in which the methanol and ethanol treatments

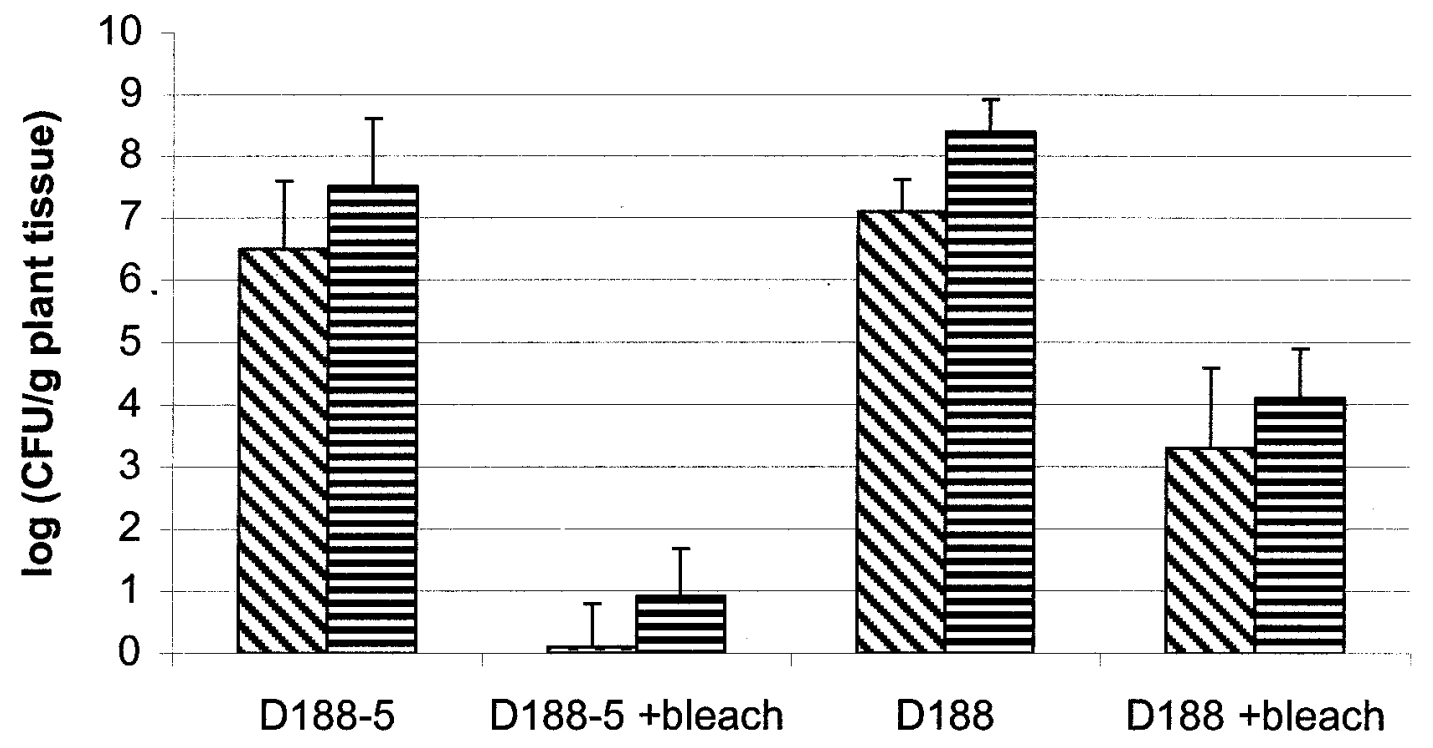

$\mathbf{\nabla} 3$ weeks $\boxminus 5$ weeks

Fig. 4. Average number of log-transformed CFU/g plant tissue from infected plants, 3 and 5 weeks after infection. Plants were infected with strain D188 or D188-5 and cut in half after harvesting. One half was treated with bleach prior to plating. A significant difference was found between the bleachtreated plants infected with D188 or D188-5 $\left(\mathrm{F}_{(1,47)}=25.2\right.$ and $\mathrm{F}_{(1,49)}=32.1 ; p<0.001$ for 3 and 5 weeks postinfection, respectively). 
were prolonged to $1 \mathrm{~h}$. The fixation time varied between 30 min and $2 \mathrm{~h}$, depending upon the size of the samples. After a gradual transfer to xylene, samples were embedded in paraplast and cut to 10 - to $30-\mu \mathrm{m}$ sections, which were mounted on silane-coated glass slides (CEL Associates, Houston, TX, U.S.A.). Paraplast was removed with xylene.

Prior to hybridization, the samples were treated as described by Bauwens et al. (1997), although different permeabilization procedures were tested: i) $1 \times$ phosphate buffered saline (PBS) with Tween 20 (Sigma, St. Louis, MO, U.S.A.) (PBT); ii) 40 $\mu \mathrm{g}$ of proteinase $\mathrm{K}$ per $\mathrm{ml}$ in $1 \times \mathrm{PBT}$; iii) $0.1 \% \mathrm{SDS}$ in $1 \times$ PBT; and iv) $40 \mu \mathrm{g}$ of proteinase $\mathrm{K}$ per $\mathrm{ml}$ and $0.1 \%$ SDS in $1 \times$ PBT. The slides were left for $20 \mathrm{~min}$ in the permeabilization solution. For the whole-mount procedure, we used tobacco seedlings and the prehybridization steps were twice as long.

\section{Hybridization and posthybridization washes.}

The oligonucleotide probe Eub338 (5'-GCTGCCTCCCGTAGGAGT), homologous to 16S rRNA, was obtained with $5^{\prime}$ end labeling with tetramethyl-rhodamine from Eurogentec (Liège, Belgium) (Amann et al. 1990). The hybridization buffer, adapted from Manz et al. (1992), consisted of $20 \mathrm{mM}$ Tris (pH 7.4), $0.02 \%$ SDS, $0.9 \mathrm{M} \mathrm{NaCl}$, and $5 \mathrm{mM}$ EDTA. The oligonucleotide probe was applied at a concentration of 1 $\mu \mathrm{M}$. The hybridization was performed at $42^{\circ} \mathrm{C}$ for a minimum of $2 \mathrm{~h}$. After hybridization, the slides were washed twice (for $10 \mathrm{~min}$ ) in hybridization solution at room temperature.

Staining of the DNA was then performed with DAPI (Sigma), which was used at a concentration of $1 \mu \mathrm{g}$ per $\mathrm{ml}$ PBS. Staining of plant cell walls was performed with a $0.2 \%$ (wt/vol) solution of calcofluor white M2R (also called fluorescent brightener 28) (Sigma) in PBS for $2 \mathrm{~min}$. The slides were mounted with Vectashield-mounting medium (Vector Laboratories, Burlingame, CA, U.S.A.). With bacterial cultures, the different permeabilization procedures made it possible to detect single cells. A comparison was done of the autofluorescence of the plant (stem and leaf) material, following the two different fixation methods. Fixation with ethanolacetic acid gave rise to a higher autofluorescence of the plant material with filter block 15 on the Axioskop epifluorescent microscope (Zeiss, Jena, Germany) than with the two-phase fixation. On uninfected plants, no signal was obtained.

\section{Histochemical staining.}

Histochemical staining with alcian green safranin was performed as described by Gurr (1965), and reagents were purchased from Sigma. Slides with sections of paraplastembedded plant material were mounted in Depex mounting medium (BDH, Poole, U.K.).

Complete plants were first cleared in boiling ethanol, followed by a hydration to $50 \%$ ethanol, then put in the staining mix for $10 \mathrm{~min}$, briefly washed in $50 \%$ ethanol, and dehydrated in an ethanol series.

\section{Epifluorescence microscopy.}

An Axioskop microscope was used with a 20x Fluar lens (Zeiss) and a 40× Achroplan lens (Zeiss). To visualize the DAPI-stained DNA and the plant cell walls stained with calcofluor white, filter block 02 was used, which consists of a G 365 excitation filter, an FT 395 beam splitter, and a LP 420 barrier filter. Signals from the oligonucleotide probe (tetrame- thyl-rhodamine) were visualized with filter block 15 , which consists of a BP 546/12 excitation filter, a FT 580 beam splitter, and a LP 590 barrier filter.

\section{Confocal microscopy.}

An Axiovert $100 \mathrm{M}$ confocal microscope (Zeiss) was used with a $20 \times$ and $40 \times$ lens and LSM510 software (release 2.0). UV excitation was obtained with a laser at $364 \mathrm{~nm}$ to visualize the DAPI-stained DNA and the plant cell walls stained with calcofluor white. The signal from the oligonucleotide probe (tetramethyl-rhodamine) was excitated with a helium-neon laser at $543 \mathrm{~nm}$.

\section{SEM.}

Samples were fixed in $4 \%$ formaldehyde and $1 \%$ glutaraldehyde in $0.1 \mathrm{M}$ cacodylate buffer $(\mathrm{pH} 7.2)$ overnight at $4^{\circ} \mathrm{C}$. Postfixation was performed in $2 \% \mathrm{OsO}_{4}$ in $\mathrm{H}_{2} \mathrm{O}$ overnight at $4^{\circ} \mathrm{C}$. Samples were dehydrated in an ethanol series and dried in liquid $\mathrm{CO}_{2}$ with a critical point dryer, mounted on stubs with double-stick adhesive, and gold coated with a sputter coater. The samples were viewed with a Jeol JSM 840 microscope (Jeol-Europe B.V., Schipholrijk, The Netherlands).

\section{Cryo-SEM.}

Samples were mounted with carbon black paste and frozen in liquid nitrogen slush. The mounted sample was transferred under liquid nitrogen to a CT $1500 \mathrm{HF}$ cryo-transfer system (Oxford Instruments, Eynsham, U.K.), etched for $3 \mathrm{~min}$ at $-89^{\circ} \mathrm{C}$ and $10^{-4} \mathrm{~Pa}$, sputter-coated with platinum, and transferred to the cooled sample stage of a field-emission SEM (Jeol 6300 F).

\section{Determination of CFUs.}

A two-by-two factorial design (bacterial strain by treatment) was employed. Four-week-old tobacco plants infected by dipping were harvested 3 and 5 weeks after infection. The plants were cut symmetrically in two, and both halves were weighed. One half of each plant was submitted to a bleach treatment (6\% sodium hypochloride) and washed twice for $1 \mathrm{~min}$ in sterile water. Both plant halves were crushed with a pestle, diluted, and plated. The mean CFU of each plant half per unit weight of plant tissue was determined. Bacterial populations were $\log$ transformed prior to statistical analysis. Contribution of strain and treatment to the number of CFU per g plant tissue was assessed by performing a two-way analysis of variance with Statistica (Statsoft, Tulsa, AZ, U.S.A.).

\section{ACKNOWLEDGMENTS}

We thank R. Van Driesschen for scanning electron microscopy, D. Vereecke and K. Senti for critical reading of the manuscript, and S. Debruyne for help with the figures. This work was supported by a grant from the Interuniversity Poles of Attraction Programme (Belgian State, Prime Minister's Office-Federal Office for Scientific, Technical and Cultural Affairs; P4/15). T. Ritsema is indebted to the Netherlands Organization for Scientific Research (NWO) and the European Union for a TALENT and a Training and Mobility Research Grant (ERBFMBICT 972383), respectively. M. Jaziri is a Research Associate of the Fonds National de la Recherche Scientifique (FNRS).

\section{LITERATURE CITED}

Amann, R. I., Binder, B. J., Olson, R. J., Chisholm, S. W., Devereux, R., and Stahl, D. A. 1990. Combination of $16 \mathrm{~S}$ ribosomal RNA-targeted 
oligonucleotide probes with flow cytometry for analyzing mixed bacterial populations. Appl. Environ. Microbiol. 56:1919-1925.

Amann, R. I., Ludwig, W., and Schleifer, K.-H. 1995. Phylogenetic identification and in situ detection of individual microbial cells without cultivation. Microbiol. Rev. 59:143-169.

Bauwens, S., Verhoeyen, E., de Almeida Engler, J., Van Montagu, M., and Engler, G. 1997. Detection of mRNA via fluorescence in situ hybridization and confocal microscopy in whole mounts of roots of Arabidopsis thaliana. Plant Mol. Biol. Rep. 15:22-37.

Beattie, G. A., and Lindow, S. E. 1995. The secret life of foliar bacterial pathogens on leaves. Annu. Rev. Phytopathol. 33:145-172.

Beattie, G. A., and Lindow, S. E. 1999. Bacterial colonization of leaves: A spectrum of strategies. Phytopathology 89:353-359.

Chin-A-Woeng, T. F. C., De Priester, W., Van der Bij, A. J., and Lugtenberg, B. J. J. 1997. Description of the colonization of a gnotobiotic tomato rhizosphere by Pseudomonas fluorescens biocontrol strain WCS365, using scanning electron microscopy. Mol. PlantMicrobe Interact. 10:79-86.

Crespi, M., Messens, E., Caplan, A. B., Van Montagu, M., and Desomer, J. 1992. Fasciation induction by the phytopathogen Rhodococcus fascians depends upon a linear plasmid encoding a cytokinin synthase gene. EMBO J. 11:795-804.

Crespi, M., Vereecke, D., Temmerman, W., Van Montagu, M., and Desomer, J. 1994. The fas operon of Rhodococcus fascians encodes new genes required for efficient fasciation of host plants. J. Bacteriol. 176:2492-2501.

De Buck, S., De Wilde, C., Van Montagu, M., and Depicker, A. 2000. Determination of the T-DNA transfer and the T-DNA integration frequencies upon cocultivation of Arabidopsis thaliana root explants. Mol. Plant-Microbe Interact. 13:658-665.

DeLong, E. F., Wickham, G. S., and Pace, N. R. 1989. Phylogenetic stains: Ribosomal RNA-based probes for the identification of single cells. Science 243:1360-1363.

Desomer, J., Dhaese, P., and Van Montagu, M. 1988. Conjugative transfer of cadmium resistance plasmids in Rhodococcus fascians strains. J. Bacteriol. 170:2401-2405.

Faivre-Amiot, A. 1967. Quelques observations sur la présence de Corynebacterium fascians (Tilford) Dowson dans les cultures maraichères et florales en France. Phytiatr.-Phytopharm. 16:165-176.

Goodfellow, M. 1984. Reclassification of Corynebacterium fascians (Tilford) Dowson in the genus Rhodococcus, as Rhodococcus fascians comb. nov. Syst. Appl. Microbiol. 5:225-229.

Gurr, E. 1965. The Rational Use of Dyes in Biology and General Staining Methods. Leonard Hill, London.

Hadri, A.-E., and Bisseling, T. 1998. Responses of the plant to Nod factors. Pages 403-416 in: The Rhizobiaceae: Molecular Biology of Model Plant-Associated Bacteria. H. P. Spaink, A. Kondorosi, and P. J. J. Hooykaas, eds. Kluwer Academic Publishers, Dordrecht, The Netherlands.

Hugouvieux, V., Barber, C. E., and Daniels, M. J. 1998. Entry of Xanthomonas campestris pv. campestris into hydathodes of Arabidopsis thaliana leaves: A system for studying early infection events in bacterial pathogenesis. Mol. Plant-Microbe Interact. 11:537-543.

Koenig, D. P., Perdreau-Remington, F., Ruett, J., Stossberger, P., Hilgers, R. D., and Plum, G. 1998. Slime production of Staphylococcus epidermidis: Increased bacterial adherence and accumulation onto pure titanium. Acta Orthop. Scand. 69:523-526.

Lacey, M. S. 1936a. The isolation of a bacterium associated with "fasciation" of sweet peas, "cauliflower" strawberry plants and "leafy gall" of various plants. Ann. Appl. Biol. 23:302-310.

Lacey, M. S. 1936b. Further studies on a bacterium causing fasciation of sweet peas. Ann. Appl. Biol. 23:743-751.

Lacey, M. S. 1961. The development of filter-passing organisms in
Corynebacterium fascians cultures. Ann. Appl. Biol. 49:634-644.

Macnaughton, S. J., O'Donnell, A. G., and Embley, T. M. 1994. Permeabilization of mycolic-acid-containing actinomycetes for in situ hybridization with fluorescently labelled oligonucleotide probes. Microbiology 140:2859-2865.

Macnaughton, S. J., Booth, T., Embley, T. M., and O'Donnell, A. G. 1996. Physical stabilization and confocal microscopy of bacteria on roots using 16S rRNA targeted, fluorescent-labeled oligonucleotide probes. J. Microbiol. Methods 26:279-285.

Manes, C.-L., Van Montagu, M., Prinsen, E., Goethals, K., and Holsters, M. 2001. De novo cortical cell division triggered by the phytopathogen Rhodococcus fascians in tobacco. Mol. Plant-Microbe Interact. 14:189-195.

Manz, W., Amann, R., Ludwig, W., Wagner, M., and Schleifer, K. H. 1992. Phylogenetic oligodeoxynucleotide probes for the major subclasses of proteobacteria: Problems and solutions. Syst. Appl. Microbiol. 15:593-600.

Matzk, A., Mantell, S., and Schiemann, J. 1996. Localization of persisting agrobacteria in transgenic tobacco plants. Mol. Plant-Microbe Interact. 9:373-381.

Miguélez, E. M., Martín, C., Manzanal, M. B., and Hardisson, C. 1992. Growth and morphogenesis in Streptomyces. FEMS Microbiol. Lett. 100:351-360.

Miller, H. J., Janse, J. D., Kamerman, W., and Muller, P. J. 1980. Recent observations of leafy gall in Liliaceae and some other families. Neth. J. Plant Pathol. 86:55-68.

Miller, J. H. 1972. Experiments in Molecular Genetics. Cold Spring Harbor Laboratory, Cold Spring Harbor, NY, U.S.A.

Nagata, T., Nemoto, Y., and Hasezawa, S. 1992. Tobacco BY-2 cell line as the "HeLa" cell in the cell biology of higher plants. Int. Rev. Cytol. 132:1-30.

Nap, J.-P., and Bisseling, T. 1990. Developmental biology of a plantprokaryote symbiosis: The legume root nodule. Science 250:948-954.

Pennell, R. I., and Lamb, C. 1997. Programmed cell death in plants. Plant Cell 9:1157-1168.

Raad, I., Darouiche, R., Hachem, R., Sacilowski, M., and Bodey, G. P. 1995. Antibiotics and prevention of microbial colonization of catheters. Antimicrob. Agents Chemother. 39:2397-2400.

Saile, E., McGarvey, J. A., Schell, M. A., and Denny, T. P. 1997. Role of extracellular polysaccharide and endoglucanase in root invasion and colonization of tomato plants by Ralstonia solanacearum. Phytopathology 87:1264-1271

Souli, M., and Giamarellou, H. 1998. Effects of slime produced by clinical isolates of coagulase-negative staphylococci on activities of various antimicrobial agents. Antimicrob. Agents Chemother. 42:939-941.

Tilford, P. E. 1936. Fasciation of sweet peas caused by Phytomonas fascians n. sp. J. Agric. Res. 53:383-394.

Vasse, J., Frey, P., and Trigalet, A. 1995. Microscopic studies of intercellular infection and protoxylem invasion of tomato roots by Pseudomonas solanacearum. Mol. Plant-Microbe Interact. 8:241-251.

Vereecke, D., Messens, E., Klarskov, K., De Bruyn, A., Van Montagu, M., and Goethals, K. 1997. Patterns of phenolic compounds in leafy galls of tobacco. Planta 201:342-348.

Vereecke, D., Burssens, S., Simón-Mateo, C., Inzé, D., Van Montagu, M., Goethals, K., and Jaziri, M. 2000. The Rhodococcus fasciansplant interaction: Morphological traits and biotechnological applications. Planta 210:241-251.

Wildermuth, H. 1970. Development and organisation of the aerial mycelium in Streptomyces coelicolor. J. Gen. Microbiol. 60:43-50.

Yu, J., Peñaloza-Vázquez, A., Chakrabarty, A. M., and Bender, C. L. 1999. Involvement of the exopolysaccharide alginate in the virulence and epiphytic fitness of Pseudomonas syringae pv. syringae. Mol. Microbiol. 33:712-720. 